\title{
Study on knowledge and experience about emergency contraception at a tertiary care centre family planning clinic
}

\section{Lakshmidevi M.*, Sheela H. S., Shreedhar Venkatesh}

Department of Obstetrics and Gynecology, Vydehi Institute of Medical Sciences and Research Centre, Bangalore, Karnataka, India

Received: 01 October 2018

Accepted: 13 November 2018

\section{*Correspondence:}

Dr. Lakshmidevi M.,

E-mail: dr_lakshmi_m1982@yahoo.co.in

Copyright: () the author(s), publisher and licensee Medip Academy. This is an open-access article distributed under the terms of the Creative Commons Attribution Non-Commercial License, which permits unrestricted non-commercial use, distribution, and reproduction in any medium, provided the original work is properly cited.

\begin{abstract}
Background: Unintended pregnancies and unsafe abortions are the major reproductive health challenges faced by women of developing countries. According to WHO 42 million induced abortions occur annually and out of which 20 million are performed in unsafe condition and by unskilled providers.

Methods: It is a questionnaire-based study planned to be conducted in the family planning clinic of Department Of Obstetrics and Gynaecology, at Vydehi Institute of Medical Sciences and Research Centre, Bangalore. Statistical analysis is done by percentage analysis, paired T test or Wilckoxer signed rank test and Mcnemer test.

Results: This is a questionnaire-based study conducted on 300 urban educated women seeking termination of pregnancy. Among 300 women studied majority were in the age group of 21-30 years i.e. 174 women (58\%). Among 300 women studied about 126 women who had some knowledge about EC and Medias (like TV, radio and magazine) constitutes the major source of knowledge i.e. 60 women (47.6\%) then Doctors and nurse i.e. 36 women (28.5\%) and other sources like friends, relative and Teachers i.e. 30 women $(23.8 \%)$. Knowledge about the side effects of EC was very limited in present study, i.e. 30 women (23.8\%) were unaware of side effects, 60 women (47.6\%) were aware of minor side effects like nausea, vomiting and pain abdomen, and only 36 women (28.5\%) were aware of hormonal side effects like menstrual irregularity.

Conclusions: From present study it is shown that even among urban educated women knowledge about emergency contraception is very limited. For the proper use of emergency contraception, women should have basic knowledge about fertility and contraception. According to present study only $23.8 \%$ of urban educated women have knowledge about safe and unsafe period only $(42.8 \%)$ had knowledge about timing of use of Emergency contraception.
\end{abstract}

Keywords: Abortion, Emergency contraception, Family planning clinic

\section{INTRODUCTION}

Unintended pregnancies and unsafe abortions are the major reproductive health challenges faced by women of developing countries. According to WHO 42 million induced abortions occur annually and out of which 20 million are performed in unsafe condition and by unskilled providers. According to ICMR study in India, 6.1 legal abortions per thousand live birth and 13.5 illegal abortions per 1000 live births are performed every year in the country. Unsafe abortions contribute to almost $13 \%$ of maternal mortality, on an average 47000 deaths occur due to unsafe abortions annually worldwide. ${ }^{1,2}$ Morbidity related to unsafe abortions are very high and exact picture is not known. Immediate complications include incomplete abortions, post-abortal sepsis, hemorrhage; genital trauma and long term sequale include pelvic inflammatory disease, secondary infertility and future risk of ectopic pregnancy. 
The use of contraception to prevent unwanted pregnancies and unsafe abortions is an important strategy to minimize the maternal mortality and morbidity related to abortion.

Emergency contraception is defined as a drug or a device which is used to prevent pregnancy after unprotected sexual intercourse. Options of emergency contraception include progesterone pills, oral contraceptive pills, intra uterine contraceptive device (IUCD) and other newer methods. Progesterone pills include use of levonorgesterol (LNG) pills either $1.5 \mathrm{mg}$ given in single dose or $0.75 \mathrm{mg}$ given in two doses 24 hours apart, within 72 hours of unprotected intercourse. Recent studies have shown LNG pills are effective even up to 120 hours after unprotected intercourse. On the other hand, YUZPE regimen involves use of oral contraceptive pills in larger doses, used two times 12 hours apart. IUCD can be inserted within 5 days of unprotected intercourse as emergency contraception. Newer methods include use of ulipristal acetate and mifepristone. Even though Government of India has approved the use of emergency contraception from 2001 and it is about $75-89 \%$ effective, but it has failed to produce desired impact. Important barrier for the use of emergency contraception include limited knowledge, poor understanding of concepts of fertility and limited availability. ${ }^{3}$ Even though abortion is legalized in India from 1971, unfortunately it has become a common method of limiting and spacing the birth. High rate of abortion in India reflects on low prevalence of contraceptive use. ${ }^{4,5}$

The objectives of this study are to know about the knowledge of emergency contraception of women, at a tertiary care center family planning clinic; to know about the experience of emergency contraception in women who have used it. It is taken as an opportunity to educate the women regarding emergency contraception.

\section{METHODS}

It is a questionnaire-based study planned to be conducted in the family planning clinic of Department of Obstetrics and Gynaecology, at Vydehi Institute of Medical Sciences and Research Centre, Bangalore. After obtaining the ethical clearance for the study, the participants who ever are willing to participate in the study are given a brief introduction about emergency contraception. After obtaining the consent they will be interacted about their knowledge and experience on use of emergency contraception by using questionnaire proforma, by one to one discussion. At the end of the discussion they are educated about the correct knowledge of emergency contraception and encouraged to use it whenever necessary, as a backup method and they were asked to educate the peer population regarding the correct knowledge about emergency contraception.

Proforma consisted of three parts. First part includes basic details like name, age, parity, educational status and religion. Second part includes knowledge about emergency contraception like their awareness about emergency contraception, source of knowledge, and timing of use of emergency contraception in relation to menstrual cycle and sexual intercourse, effect of emergency contraception on menstrual cycle, side effects of emergency contraception and necessity of consulting doctor before using emergency contraception. Second part consisted of their experience on the use of emergency contraception, for what purpose it was used, type of emergency contraception used, timing when it was used and their side effects and the mode of procuring emergency contraception. In the third part they were educated about the correct knowledge about emergency contraception and post education their improvement in the knowledge was assessed using the same assessment method as mentioned in the first part.

\section{Statistical analysis}

Statistical analysis is done by percentage analysis, paired $\mathrm{T}$ test or Wilckoxer signed rank test and Mcnemer test.

\section{RESULTS}

This is a questionnaire-based study conducted on 300 urban educated women seeking termination of pregnancy. Among 300 women studied majority were in the age group of 21-30 years i.e. 174 women (58\%). Majority of women seeking termination of pregnancy were primipara i.e. 174 women $(58 \%)$ followed by nullipara i.e. 84 women (28\%) and P2 and above i.e. 36 women (12\%).

Table 1: Demographic features of the study group.

\begin{tabular}{|l|l|}
\hline Demographic features & \multicolumn{1}{|l|}{ Number of cases } \\
\hline Age group & $174(58 \%)$ \\
\hline $21-30$ years & $70(23 \%)$ \\
\hline $31-40$ years & $56(19 \%)$ \\
\hline$>41$ years & \\
\hline Parity in the study group & $84(24 \%)$ \\
\hline Nullipara & $174(58 \%)$ \\
\hline Primipara & $36(12 \%)$ \\
\hline Gravid 2 and above & $170(57 \%)$ \\
\hline Educational status in the study group \\
\hline Primary and secondary education & $74(25 \%)$ \\
\hline Graduation & $56(18 \%)$ \\
\hline Post-graduation & $120(40 \%)$ \\
\hline Reason for termination of pregnancy \\
\hline Previous child is too small & $90(30 \%)$ \\
\hline Does not want more pregnancy & $30(10 \%)$ \\
\hline Failed contraception & $60(20 \%)$ \\
\hline Social and financial reason & $140(47 \%)$ \\
\hline Distribution of religion in study group \\
\hline Hindu & $50(17 \%)$ \\
\hline Muslim & $70(23 \%)$ \\
\hline Christian & $40(13 \%)$ \\
\hline Others & \\
\hline
\end{tabular}


In present study, the reasons for termination of pregnancy in majority of the women, being previous child is less than three years of age i.e. 120 women $(40 \%)$ followed by other reasons like does not want pregnancy so early after marriage i.e. 90 women $(30 \%)$, financial and social reasons i.e. 60 women $(20 \%)$ and failed contraception i.e. 30 women (10\%). Among 300 women studied 174 women $(59 \%)$ women had no knowledge about EC, 96 women $(22 \%)$ had incomplete knowledge and only 30 women $(10 \%)$ had complete knowledge and EC (Table $1)$.

Table 2: Knowledge about emergency contraception.

\begin{tabular}{|c|c|}
\hline \multicolumn{2}{|c|}{ Knowledge about emergency contraception } \\
\hline Nil & $174(59 \%)$ \\
\hline Incomplete & $96(22 \%)$ \\
\hline Complete & $30(10 \%)$ \\
\hline \multicolumn{2}{|l|}{ Source of knowledge } \\
\hline Friends, relatives and teacher & $30(23.8 \%)$ \\
\hline Television, radio and magazine & $60(47.6 \%)$ \\
\hline Doctor and para medical staff & $36(28.5 \%)$ \\
\hline \multicolumn{2}{|c|}{$\begin{array}{l}\text { Knowledge about side effects of emergency } \\
\text { contraception }\end{array}$} \\
\hline No side effects & $30(23.8 \%)$ \\
\hline Nausea, vomiting, and pain abdomen & $60(47.8 \%)$ \\
\hline $\begin{array}{l}\text { Hormonal like breast tenderness, and } \\
\text { heaviness, spotting and menstrual } \\
\text { disturbances. }\end{array}$ & $36(28.5 \%)$ \\
\hline \multicolumn{2}{|l|}{ Procuring emergency contraception } \\
\hline Over the counter & $90(71.4 \%)$ \\
\hline With the prescription of a doctor & $36(28.6 \%)$ \\
\hline \multicolumn{2}{|c|}{$\begin{array}{l}\text { Knowledge about the use of emergency } \\
\text { contraception in relation to menstrual cycle }\end{array}$} \\
\hline No knowledge & $20(15.9 \%)$ \\
\hline Both in safe and unsafe period & $60(47.8 \%)$ \\
\hline Only in safe period & $16(12.7 \%)$ \\
\hline Only in unsafe period & $30(23.8 \%)$ \\
\hline \multicolumn{2}{|c|}{$\begin{array}{l}\text { Knowledge about the use of emergency } \\
\text { contraception in relation to sexual intercourse }\end{array}$} \\
\hline No knowledge & $30(23.8 \%)$ \\
\hline Before sexual intercourse & $20(15.9 \%)$ \\
\hline Within 24 hours of sexual intercourse & $12(9.5 \%)$ \\
\hline Within 72 hours of sexual intercourse & $54(42.8 \%)$ \\
\hline \multicolumn{2}{|c|}{$\begin{array}{l}\text { Necessity of consulting a doctor for the use of } \\
\text { emergency contraception }\end{array}$} \\
\hline No necessity & $30(23.8 \%)$ \\
\hline Before using emergency contraception & $14(11.1 \%)$ \\
\hline After using emergency contraception & $70(55.5 \%)$ \\
\hline When they miss their cycle & $12(9.5 \%)$ \\
\hline
\end{tabular}

Among 300 women studied about 126 women who had some knowledge about EC and Medias (like TV, radio and magazine) constitutes the major source of knowledge i.e. 60 women $(47.6 \%)$ then Doctors and nurse i.e. 36 women $(28.5 \%)$ and other sources like friends, relative and Teachers i.e. 30 women (23.8\%). Knowledge about the side effects of EC was very limited in present study, i.e. 30 women $(23.8 \%)$ were unaware of side effects, 60 women $(47.6 \%)$ were aware of minor side effects like nausea, vomiting and pain abdomen, and only 36 women (28.5\%) were aware of hormonal side effects like menstrual irregularity.

Knowledge about the availability of emergency contraception was very limited, only 90 women (71.4\%) knew that it can be procured over the counter without prescription and 36 women $(29.6 \%)$ were of knowledge that it requires doctor's perception. Only 30 women $(23.8 \%)$ had knowledge about safe and unsafe period and use of Emergency contraception in unsafe period. Only 54 women $(42.8 \%)$ of the study group had Knowledge about the use of EC within 72 hours of unprotected sexual act (Table 2).

\section{DISCUSSION}

More than 80 million of pregnancies worldwide will end up in abortion; more than $60 \%$ of these pregnancies will take place in adolescent age group because of early sexual activity among adolescence and lack of use of contraception. $97 \%$ of these unsafe abortions take place in developing countries. An estimate of 68000 women die every year from unsafe abortions and millions more are injured permanently. Despite of its frequency, unsafe abortions remains one of the most neglected public health problems. Most of these abortions take place under unsafe and illegal conditions.

WHO estimates that about $20-30 \%$ of unsafe abortions result in reproductive tract infections and in that about $20-40 \%$ of this result in upper-genital-tract infection and infertility. An estimated $2 \%$ of women of reproductive age are infertile as a result of unsafe abortion. ${ }^{2}$ All these public health problems can be reduced by using emergency contraception. Lack of knowledge about EC was the major limiting factor for the use of emergency contraception. Emergency contraception can serve as a safe backup method of contraception for these women. In present study group $58 \%$ of women were primi para and $28 \%$ nulli para and $12 \%$ were gravid 2 and above, in comparison to Gunilla Anebloma, Margareta Larssona study where the percentages were $46 \%, 49 \%, 1 \%$ respectively. ${ }^{3}$

Among 300 women studied about 126 women who had some knowledge about EC and medias (like TV, radio and magazine) Constitutes the major source of knowledge i.e. 60 women $(47.6 \%)$ then Doctors and nurse i.e. 36 women $(28.5 \%)$ and other sources like friends, relative and Teachers i.e. 30 women $(23.8 \%)$. This is comparable to Arora N, Mittal S study in which total of $96.5 \%$ (389) volunteered graduating female students participated in the study. ${ }^{6} 41.9 \%$ (163) had ever heard of EC, and only $6.8 \%$ (11) used the method. The common sources of information in their study were friends $36.5 \%$ (60), radio $22.8 \%$ (37) and television $12.3 \%$ (20). $71.2 \%$ (113) agreed to use EC when the need arose. $^{3}$ 
Knowledge about the side effects of EC was very limited in present study i.e. 30 women $(23.8 \%)$ were unaware of side effects, 60 women $(47.6 \%)$ were aware of minor side effects like nausea, vomiting and pain abdomen, and only 36 women $(28.5 \%)$ were aware of hormonal side effects like menstrual irregularity.

In comparison to Harper $\mathrm{CC}$ et al and $56 \%$ has menstrual irregularities. Nausea was reported in by $38.5 \%$ of participants and vomiting by $11.5 \% .^{7}$ Only 54 women (42.8\%) of the study group had Knowledge about the use of EC within 72 hours of unprotected sexual intercourse in compassion only $11.5 \%$ of women in Joanne Turner, Ernest Cooke study. Among the women who had some knowledge only $30(23.8 \%)$ had used it (Table 2). ${ }^{4}$ In present study only $42.8 \%$ of the study group had knowledge about the use of EC within 72hours of unprotected sexual intercourse in compassion only $11.5 \%$ of women in study on emergency contraception conducted in Zambia. ${ }^{8}$

\section{CONCLUSION}

From present study it is shown that even among urban educated women knowledge about emergency contraception is very limited. For the proper use of emergency contraception, women should have basic knowledge about fertility and contraception. According to present study only $23.8 \%$ of urban educated women have knowledge about safe and unsafe period only (42.8\%) had knowledge about timing of use of Emergency contraception.

Therefore, explaining the number of family planning of options available is a critical part of increasing the contraception use and decreasing the number of intended pregnancies. Even in educated women, more than $1 / 4$ of women have unmet needs of contraception6. Best way to increase the use the emergency contraception is to increase the knowledge of emergency contraception.

Funding: No funding sources Conflict of interest: None declared

Ethical approval: The study was approved by the Institutional Ethics Committee

\section{REFERENCES}

1. Tesfaye T, Tilahun T, Girma E. Knowledge, attitude and practice of emergency contraceptive among women who seek abortion care at Jimma University specialized hospital, southwest Ethiopia. BMC Women's Health. 2012;12(1):3.

2. Meng CX, Gemzell-Danielsson K, Stephansson O, Kang JZ, Chen QF, Cheng LN. Emergency contraceptive use among 5677 women seeking abortion in Shanghai, China. Human Reprod. 2009;24(7):1612-8.

3. Aneblom G, Larsson M, Odlind V, Tydén $\mathrm{T}$. Knowledge, use and attitudes towards emergency contraceptive pills among Swedish women presenting for induced abortion. BJOG. 2002;109(2):155-60.

4. George J, Turner J, Cooke E, Hennessy E, Savage W, Julian P, et al. Women's knowledge of emergency contraception. Br J Gen Pract. 1994;44(387):451-4.

5. Berin E, Sundell M, Karki C, Brynhildsen J, Hammar M. Contraceptive knowledge and attitudes among women seeking induced abortion in Kathmandu, Nepal. Int J Women's Heal. 2014;6:335.

6. Arora N, Mittal S. Emergency contraception and prevention of induced abortion in India. BMJ Sexual Reprod Heal. 2005;31(4):294-6.

7. Harper CC, Rocca CH, Darney PD, von Hertzen H, Raine TR. Tolerability of levonorgestrel emergency contraception in adolescents. Am J Obstet Gynecol. 2004;191(4):1158-63.

8. Chavuma NC, Chanda DO, Vwalika B. Emergency contraception among women with abortion at university teaching hospital in Lusaka, Zambia. Med J Zambia. 2010;37(4):240-5.

Cite this article as: Lakshmidevi M, Sheela HS, Venkatesh S. Study on knowledge and experience about emergency contraception at a tertiary care centre family planning clinic. Int J Reprod Contracept Obstet Gynecol 2019;8:155-8. 